YAK 347.122(045)

DOI https://doi.org/10.32837/chc.v0i37.343

Гудима Мирослава Мирославівна,

кандиАат юриАичних наук, Аоцент, Аокторант кафеАри цивільного права

Навчально-наукового юридичного інституту

АВН3 «Прикарпатський національний університет імені Василя Стефаника»

ORCID https://orcid.org/0000-0001-6242-3445

\title{
РЕЧОВІ ПРАВА У ВІДНОСНИХ (ЗОБОВ'ЯЗАЛЬНИХ) ПРАВОВІДНОСИНАХ: ОКРЕСЛЕННЯ ТЕОРЕТИЧНОЇ ПРОБЛЕМИ
}

Постановка проблеми. Традиційний постулат цивілістики про поділ правовідносин на абсолютні та віАносні, а прав - на речові та зобов'язальні часто наштовхує науковців на формулювання висновків про можливість існування в межах віАповіАних правовіАносин тільки однойменних їм прав (у віАносних (зобов'язальних) правовіАносинах - зобов'язальних прав, а в абсолютних (зокрема, речових) правовідносинах - прав речового характеру).

Цілком очевиАно, що суб'єктивні цивільні права є елементами правовідносин і поза останніми існувати не можуть, оскільки кожному праву оАнієї сторони кореспонаує обов'язок іншої сторони (яка може бути представлена однією або кількома особами або "всіма іншими особами"). В абсолютних віАносинах змістом є суб'єктивне право особи на власну поведінку (речове право), тоді як у віАносних правовіАносинах зміст полягає у праві вимоги уповноваженої особи конкретної поведінки віА зобов'язаних осіб (право вимоги, тобто зобов'язальне право). Все частіше і Аоктрина цивільного права, і практика реалізації цивільно-правових норм стикаються з приклаАами проникнення речових елементів у віАносні (зобов'язальні) правовіАносини, що й зумовлює актуальність визначення місця речових прав у віАповіАних правовіАносинах.

Стан АосліАження теми. Проблематика правовіАносин і суб'єктивних прав завжди цікавила АосліАників-теоретиків права і науковців-цивілістів, вона не втрачає своєї популярності й нині. СереА правників-фахівців у галузі теорії права, в коло наукових інтересів яких входила вказана проблематика, можна назвати С.С. Алексєєва, Я.М. Магазінера, О.В. Малька, М.І. Матузова, ^.І. Петражицького, К.А. Флейшиц, Р.О. Ха^фіну, Є.М. Хохлову, А.М. Чечота, ^.С. Явича та інших.

В науці цивільного права проблемні питання цивільних правовіАносин і суб'єктивних цивільних прав розробляли М.М. Агарков, М.І. Брагінський, В.В. Вітрянський, Ю.С. Гамбаров, Н.Ю. Голубєва, В.П. Грибанов, І.А. Ємелькіна, О.О. Іванов, О.С. Іоффе, О.О. Красавчиков, Н.С. Кузнєцова, В.В. Ауць, Р.А. МайАаник, А.А. Малиновський, Є.О. Мічурін, С.О. Погрібний, В.Я. Погребняк, А.О. Рибалов, 3.В. Ромовська, І.В. Спасибо-Фатєєва, М.О. Стефанчук, Ю.К. Толстой, Є.О. Харитонов, Г.Г. Харченко, В.В. Цюра, С.І. Шимон та інші.

Проте переважна більшість науковців Аотримується класичних поглядів щодо існування однойменних прав тільки в рамках однойменних правовіАносин, а небажання науковців визнати можливість існування речових прав у зобов'язальних правовідносинах зумовило виникнення на мою Аумку теоретично "хибних" концепцій щодо визнання "змішаних цивільних правовіАносин" і "змішаних цивільних прав". Такий стан Аоктринальних АосліАжень потребує нових піАходів до АосліАження вказаної проблематики і перегляду хоч і традиційних, але не Аосконалих теоретичних наукових розробок.

Мета статті полягає в АосліАженні можливості існування речових прав у зобов'язальних правовідносинах і виявлення їх місця в системі елементів останніх.

ВикиаА основного матеріалу АосліАження з повним обґрунтуванням отриманих наукових резуль- 
татів. Зауважу, що підтримую позицію теоретичної неспроможності конструкції змішаних прав чи змішаних правовіАносин і заперечую можливість існування гібриАних форм правовіАносин і прав. ЗАаєтьс, що корінь теоретичних похибок лежить у віАсутності чіткого розуміння юриАичних Аихотомій абсолютні-відносні правовідносини, речові-зобов'язальні права. Хоча категорії прав і правовіАносин насправді взаємопов'язані, але вони $€$ різнопоряАковими і мають якісні, принципові й непереборні вілмінності.

ОАне і те ж право не може бути одночасно і речовим, і зобов'язальним, так само як відносини - і абсолютними, і віАНосними воАночас. Абсолютність і віАносність є самостійними якісними родовими характеристиками внутрішнього змісту правовіАносин і можуть розглядатися як внутрішні властивості його структури. Поняття абсолютності та віАносності $€$ автономними і рівнооб'ємними, їх перетин або підпорядкування не можливі з огляду на принципові сутнісні віАмінності. Речові та зобов'язальні права також завжди будуть чітко віАокремлюватися оАні віА оАних.

Проведення чіткого окреслення меж застосування конструкцій "віАносні правовіАносини", "абсолютні правовіАносини", "речові права", “зобов' язальні права" та формулювання висновку про неможливість існування гібридних форм "абсолютно-віАносних правовіАносин" і "речово-зобов'язальних прав" аж ніяк не означає визнання того, що у віАносних правовіАносинах можуть мати місце тільки зобов'язальні права. Як стверажує С.А. Сініцин, специфіка суб'єктивного цивільного права (речового, зобов'язального, інтелектуального) не визначає необхідності модемювання віАповіАних йому за назвою виАових правовіАносин [1, с. 558].

I хоча стан сучасної цивілістики такий, що, зАійснюючи розмежування речових і зобов'язальних прав та правовіАносин, юридична наука зіткнулася з труднощами небажання визнати можливість наявності в особи речових прав у зобов'язальних за класичними канонами правовіАносинах [2, с. 281], все ж вважаю, що циві^істика має переорієнтувати свої погляАи й змиритися з можливістю проникнення речових прав у віАносні правовідносини. Проте наявність речових прав у віАносних (зобов'язальних) правовіАносинах не впливає на їх правову природу і вони й налалі характеризуватимуться чіткою визначеністю учасників.

Не цілком погоджуюся 3 Р.А. Майдаником, але все ж наведу його тезу з приводу незмінності зобов'язальної правової природи явища навіть за умов проникнення в нього речових елементів. Науковець зазначає, що низка зобов'язань з окремими речово-правовими "вкрапленнями" не втрачають зобов'язально-правової природи в силу відсутності необхіАного мінімуму кількості речово-правових елементів, які б Аавали змогу носію віАповіАного права безпосередньо впливати на річ без вирішальної Аопомоги інших зобов'язаних осіб [3, с. 31-38]. В продовження цієї позиції наведу цитату О.О. Манько: “Виникнення віАносних правовідносин при реалізації речового права зовсім не свідчить про те, що це право сліА віАносити Ао зобов'язального, воно не втрачає своїх речових властивостей: безпосереАнього отримання корисних властивостей віА речі шляхом активних Аій [4, с. 74].

Конкретний приклаА такої правової ситуації наводить Г.Г. Харченко, який, посилаючись на правовіАносини, що виникають між співвласниками, пише, що внутрішні зв'язки між співвласниками виникають не на базі їх зобов'язальних прав, а з їх речового права власності, яке, будучи різновидом речових прав, може виявлятися і в речових, і в зобов'язальних правовіАносинах [5, с. 60-61].

Загалом можна погодитися з такою позицією, але така аргументація Г.Г. Харченка виглядає сумнівною, базуючись на тому, що саме абсолютне право стосовно кожної конкретної ситуації може розглядатися і як відносне, при цьому за такого перетворення воно не втрачатиме притаманних йому ознак, аАже вже є сумою таких відносних прав [5, с. 60-61].

По-перше, не зовсім логічним мені зАається вживання автором поняття “прав" і визнання можливості їх перетворення в ключі його чітких висновків з приводу визнання різнопорядковості явищ "прав" і "правовіАносин", обрання різних критеріїв їх поділу. По-друге, вважаю, що немає підстав і сенсу заперечувати факт того, що зАійснення абсолютного (речового) права може призвести Ао виникнення одного або декількох віАносних правовіАносин між правомочною і вже конкретною особою (як в ситуації зі співвласниками чи у випадку порушення речового права і виникнення вже віАносних віАносин щодо віАповідальності), але мені зАається, що в в таких випадках виникає нова правова модель взаємовіАносин, а не видозмінюються існуючі правовіАносини абсолютного типу.

Так відбувається і у виявленому прикладі права спільної власності, коли виникають Ава окремих 
правовідношення: між співвласниками (відносні правовіАносини) з приводу реалізації речового права власності та між співвласниками як управомоченим суб'єктом і всіма третіми пасивно зобов'язаними особами (абсолютні) правовідносини. В ключі піАнятої проблематики цілком слушними є висновки М.М. Агаркова з приводу того, що віАмінність абсолютних і віАносних правовіАносин є відмінністю саме правовідносин, а не інститутів. В оАному і тому ж правовому інституті правовіАносини можуть бути як абсолютними, так і віАносними [6, с. 31-32].

Конструкція відносин спільної власності продемонструвала один із прикладів існування речових прав у зобов'язальних правовідносинах, коли відносні правовідносини виникають при реалізації речового права. “Зобов’язальні права таким чином виконують Аопоміжну функцію в реалізації речових прав у відносних правовідносинах" [7, с. 45-49]. Проте, на мою Аумку, існують і такі правові ситуації, за яких відносні правовідносини забезпечують Аинаміку речових прав, зокрема забезпечуючи перехіА речових прав віА оАного суб'єкта до іншого.

Як слушно зазначає Г.Г. Харченко, перехіА осіб віА оАного майнового стану Ао іншого зАебільшого не можливий без їх вступу в зобов'язальні правовіАносини, що і зумовлює необхідність чіткого визначення кола осіб, які беруть участь у цьому правовіАношенні [7, с. 45-49; 2, с. 283]. Отже, констатую, що речові права можуть мати місце і в абсолютних, і у відносних правовідносинах, але їх місце та правове призначення у вказаних правовіАносинах буде різним. Речові правовіАносини зводяться Ао фіксації юридичної влаАи особи розпорядитися своїм правом [8, с. 164]. Речові права в рамках цих правовіАносин складатимуть їх зміст, а об'єкт таких правовіАносин - індивіАуально визначена річ. У віАносних (зобов'язальних) правовіАносинах речові права не складатимуть змісту правовіАносин, аАже вони тут мають інше призначення - виступатимуть об'єктом цих правовіАносин.

Я цілковито розмежовую віАносні та зобов'язальні правовідносини і розглядаю в якості різноплощинних, самостійних і паралельних явищ, навіть якщо елементом і одних, і інших є одне й те ж право (скажімо, речове право). С.І. Шимон говорить про "свої" та “інші правовіАносини, зазначаючи, що у "своєму власному" правовіАношенні суб'єктивне право виступає елементом його змісту, а об'єктом може стати виключно в «іншому» правовіАношенні [9, с. 127].
Подібну позицію займає Ю.Г. Басін, зазначаючи, що право $є$ змістом правовіАношення тоді, коли йдеться про право учасника того самого правовіАношення, об'єкт якого ми визначаємо. Якщо ж суб'єкт цього правовіАношення набуває права учасника іншого правовіАношення, то це (чуже А^я нього) право стає об'єктом його суб'єктивного права [10, с. 41]. Тобто, речове право перебуває у специфічних системних зв'язках кількох рівнів: в оАних правовіАносинах (абсолютного типу) - в якості склаАника їх змісту, в межах якого існує як певне повноваження (суб'єктивне право), а в інших правовідносинах (відносного характеру) - в ролі об'єкта, який піАлягає, скажімо, переходу віА одного суб'єкта до іншого.

Як стверджує С.І. Шимон, на стадії придбання певного суб'єктивного майнового права, яке належить іншій особі, це право набуває властивостей об'єкта того правовіАношення, Ао якого вступає суб'єкт. У процесі зАійснення цього майнового права воно є змістом правовідношення, в межах якого реалізується. Авторка уточнює, що суб'єктивне право може бути об'єктом правовіАношення, якщо воно передається віА однієї особи Ао іншої [11, с. 164].

В літературі висловлюється Аумка, що право може виступати об'єктом зобов'язальних правовідносин, тобто право в Аинаміці. В статиці ж право $€$ склаАником змісту правовідношення [12, с. 72]. Проте науковці, визнаючи можливість права виступати об'єктом зобов'язальних правовіАносин, АОхоАять хибного висновку, що йАеться про право вимоги (зобов'язальне право), тоді як практика Аосить часто Аемонструє випаАки, в яких саме речове право виступає об'єктом зобов'язальних правовіАносин.

^.А. Чеговадзе стверджує, що "немає ніяких віАмінностей у суб'єктивному цивільному праві незалежно віА того, яке воно - речове або зобов'язальне" [13, с. 18]. Тому влучним є вислов^ювання С.І. Шимон, що з того факту, що майнове право є об'єктом зобов'язальних правовіАносин, не випливає висновок, що таким майновим правом може бути виключно зобов'язальне право [9, с. 127].

ПіАтверАження можливості речових прав бути об'єктом правовіАносин знаходжу шляхом анамізу законодавчих норм і практики їх реалізації. Вітчизняне законодавство визнає за деякими речовими правами на чужі речі властивість об'єктів правовіАносин (зокрема, зАатність виступати об'єктом правочинів). Так, ч. 2 ст. 413 Цивільного кодексу (Аалі - ЦК) України закріпила, що 
за загальним правилом право користування земельною Аілянкою, наАаною Аля забудови (суперфіцій), може відчужуватися або передаватися землекористувачем у порядку спадкування, крім певних винятків, встановлених законодавством; аналогічна властивість визнана за правом користування чужою земельною Аілянкою Аля сільськогосподарських потреб (емфітевзисом) (ч. 2 ст. 407 ЦК України).

І.В. Спасибо-Фатєєва стверджує, що, будучи правами майновими, а отже - об'єктами права (ч. 2 ст. 190 ЦК України), Ао того ж оборотозАатними (ст. 178 ЦК України), права на чуже майно можуть вільно обертатися. Тобто, авторка визнає за деякими правами на чуже майно якості оборотозАатності, констатуючи їх можливість виступати об'єктом правовіАносин [14, с. 63].

Конструкція Аоговірного встановлення обмежених речових прав передбачає існування віАносного зв'язку (між власником і володільцем обмеженого речового права) як такого, яке характеризується чіткою визначеністю суб'єктів правовіАношення. Проте зобов'язальний характер правовіАносин, об'єктом яких виступають права, ще не $є$ свідченням того, що переходу піАлягають тільки права вимоги, аАже різновидом майнових прав $€$ також речові права, які на підставі право- чинів чи інших юриАичних фактів у віАповіАних зобов'язальних правовіАносинах можуть перехоАити віА оАних суб'єктів Ао інших. Тому речові права можуть бути склаАниками структури не мише речових, а й зобов'язальних правовіАносин, але в якості їх різних структурних елементів.

Висновки 3 АосліАження та перспективи подальших розвіАок у цьому напрямі. Отже, характер речового права апріорно не визначає характер правовідносин, в межах яких відбувається його виникнення та реалізація. Юридична практика демонструє правові конструкції, які свіАчать, що речові права можуть бути склаАниками структури не лише абсолютних, а й віАносних правовіАносин, з чим АовоАиться змиритися цивілістичній Аоктрині та сформулювати новітні погляАи в АосліАженні вказаної проблематики.

Констатую, що речове право перебуває у специфічних системних зв'язках кількох рівнів: в одних правовідносинах (абсолютного типу) в якості склаАника їх змісту, в межах якого існує як певне повноваження на власні дії (суб'єктивне цивільне право), а в інших правовідносинах (віАносного характеру) - в ролі об'єкта (блага, заради якого суб'єкти вступають і зАійснюють відповідні правовідносини), що піляягає, скажімо, переходу віА оАного суб'єкта Ао іншого.

\section{NITEPATУPA:}

1. Синицын С.А. Общее учение об абсолютных и относительных субъективных гражданских правах : диссертация доктора юрид. наук: 12.00.03. Москва, 2017. 604 с.

2. Харченко Г.Г. Кваліфікаційний критерій визначення речових прав. Держава і право. Випуск 52. С. $278-284$.

3. Майданик Р.А. Правова природа інституту іпотеки. Юридичний вісник. Повітряне і космічне право. 2009. № 1. С. 31-38.

4. Манько Е.А. Признаки ограниченных вещных прав. Вестник Воронежского государственного ун-та. Серия «Право». 2008. № 2. С. $70-79$.

5. Харченко Г.Г. Речові права в законодавстві, доктрині та судовій практиці України : дис. докт. юрид. наук: 12.00.03. Київ, $2018.506 \mathrm{c}$.

6. Агарков М.М. Обязательство по советскому гражданскому праву. М. : Юридическое издательство НКЮ СССР, 1940.192 с.

7. Харченко Г.Г. Перехід речових прав за договором (каузальна та абстрактна моделі). Підприємництво, господарство і право.2019. № 1. С. 45-49.

8. Білоцький О.В. Розмежування речових і зобов'язальних прав користування чужим житлом. Науковий інформаційний вісник. Право. 2014. № 9. С. 163-167.

9. Шимон С.І. Теоретичні передумови виокремлення майнових прав як об'єктів цивільних правовідносин. Наукові записки Інституту законодавства Верховної Ради України. 2012. № 5. С. 125-128.

10. Басин Ю.Г. Блага и права как объекты гражданских правоотношений по казахстанскому законодательству. Объекты гражданских прав : Материалы международной научно-практической конференции. Алматы, 25-26 сентября 2003 г. Алматы : Каз ГЮУ, 2004. С. 39-44.

11. Шимон С.І. Конструкція «право на право» як концент цивільно-правової доктрини. Правове регулювання економіки. 2017. № 16. C. $161-170$.

12. Лисенко А.Н. Имущество в гражданском праве России. М. : Деловой двор, 2010. 200 с.

13. Чеговадзе Л.А. Структура и состояние гражданского правоотношения. М. : Статут, 2004. 539 с.

14. Спасибо-Фатєєва І.В. Речові права за Цивільним і Господарським кодексом України. Право України. 2015. № 4. С. 60-68.

\section{Гудима Мирослава Мирославівна РЕЧОВІ ПРАВА У ВІАНОСНИХ (ЗОБОВ'ЯЗАЛЬНИХ) ПРАВОВІАНОСИНАХ: ОКРЕСАЕННЯ ТЕОРЕТИЧНОӤ ПРОБАЕМИ}

Наукова публікація присвячена дослідженню можливості існування речових прав у зобов'язальних правовіАносинах і виявленню їх місця в системі елементів останніх. ТраАиційний постулат цивілістики про поділ правовіАносин на абсолютні та відносні, а прав - на речові та зобов'язальні часто наштовхує науковців на формулювання 
висновків про можливість існування в межах відповідних правовідносин тільки однойменних їм прав. Проте все частіше і доктрина цивільного права, і практика реалізації цивільно-правових норм стикаються з прикладами проникнення речових елементів у відносні (зобов'язальні) правовідносини.

Виявлено, що сучасний стан цивілістичної Аоктрини свідчить про небажання науковців визнати можливість наявності в особи речових прав у зобов'язальних за класичними канонами правовідносинах, що призводить до розробки та піАтримання теоретично “хибних", на мою Аумку, концепцій "змішаних цивільних правовіАносин" і "змішаних цивільних прав".

У роботі окреслено позицію щодо заперечення можливості існування гібридних форм правовіАносин та прав і виявлено необхідність чіткого розмежування теоретичних конструкцій юридичних Аихотомій абсолютні-відносні правовідносини, речові-зобов'язальні права. Водночас здійснено застереження, що таке різке протиставлення АосліАжуваних категорій аж ніяк не є визнанням факту наявності у відносних правовіАносинах тільки зобов'язальних прав. Характер речового права апріорно не визначає характер правовіАносин, в межах яких віАбувається його виникнення та реалізація.

У публікації доведено, що речові права можуть мати місце і в абсолютних, і у відносних правовідносинах, але ї правове призначення у вказаних правовідносинах буде різним. Встановлено, що речове право перебуває у специфічних системних зв'язках кількох рівнів: в оАних правовідносинах (абсолютного типу) - в якості складника їх змісту, в межах якого існує як певне повноваження на власні дії (суб'єктивне цивільне право), а в інших правовідносинах (віАносного характеру) - в ролі об'єкта, що піАлягає, скажімо, переходу віА оАного суб'єкта Ао іншого. Тим самим у роботі підтримана концепція можливості визнання права об'єктом зобов'язальних правовіАносин, Ао того ж не тільки в значенні права вимоги (зобов'язального права), що є традиційним Аля сучасної цивілістики, а саме речового права, що теж може виступати в такій іпостасі.

Киючові слова: речові права, зобов'язальні права, абсолютні правовіАносини, віАносні правовіАносини, зміст, об'єкт правовідносин.

\section{Hudyma Myroslava}

\section{PROPERTY RIGHTS IN RELATIVE (LIABILITY) LEGAL RELATIONS: A THEORETICAL PROBLEM OUTLINING}

This scholarly paper is devoted to the study of the possibility of the existence of real rights in liability legal rights and to find their place in the system of elements of the latter. The traditional tenet of the civil law on the division of legal relations into absolute and relative, and accordingly into real and liability rights, often pushes scholars to make conclusions about the possibility of existence of only the eponymous rights within the respective legal relations.

However, the doctrine of civil law, and the practice of implementing civil law, increasingly confront the examples of the penetration of material elements into relative (liability) legal relations. The article reveals that the present state of the civil law doctrine testifies to the scientists' reluctance to recognize the possibility of having a person's real rights in liability legal relations, by classical canons, which leads to the development and supporting of theoretically "false", in our opinion, concepts of "mixed civil legal relations" and "mixed civil rights".

The paper adopts the position of denying the possibility of the existence of hybrid forms of legal relations and rights and the need for a clear delineation of the theoretical constructs of legal dichotomies of absolute-relative legal relations, substantive-liability rights is revealed. At the same time, the reservation is made that such a sharp juxtaposition of the studied categories is not in any way an acknowledgment of the fact that there are only liability rights in relative legal relations. The nature of substantive law does not a priori determine the nature of the legal relations within which its origin and realization occur.

The article proves that property rights can take place in both absolute and relative relations, but their legal purpose will be different in these relations. It has been established that property rights are in specific systemic relationships of several levels: in some legal relations (of an absolute type) - as a component of their content, within which there is as a certain authority for their own actions (subjective civil law), and in other legal relations (of a relative nature) in the role of an object subject to a transition from one subject to another. In this way, the concept of the possibility of recognizing an object's right of liability legal relations is endorsed, moreover, not only in the meaning of the right of claim (liability law), which is traditional for modern civil law, namely, property law, which can also act in such a hypostasis.

Key words: property rights, liability rights, absolute legal relations, relative legal relations, content, object of legal relations. 